was $1.5 \mathrm{mgm}$. $/ \mathrm{hr}$. of acetic acid per gm. of polyvinyl acetate. This rate of acetic acid evolution decreased with time without impairing the efficiency of the column. In all studies the base line drift was less than $\pm .02 \mathrm{mV}$. The infra-red spectra of the products collected at $230^{\circ} \mathrm{C}$. over a $12-\mathrm{hr}$. period indicated the presence of acetic acid only. Thus, if the fatty acid methyl esters separated by the use of a polyvinyl acetate column are collected for further study, any trace impurities from the column can be readily removed, or easily compensated for in spectrophotometric studies.

The results reported in Table 1 were obtained using a polyvinyl acetate polymer of a rather low degree of polymerization with a molecular weight of approximately 1500. Similar results were obtained with a polyvinyl acetate polymer of molecular weight of approximately 23,000 .



* Retention volumes calculated for a flow-rate of $83 \mathrm{ml} . / \mathrm{min}$. and measured from the time of emergence of the solvent phase.

An 8-ft. coiled copper column, $\frac{1}{4}$ in. outside dia meter and wall thickness 0.03 in., was used. The partition medium consisted of 15 per cent polyvinyl acetate, designated as 'Vinylite $A Y A C^{\prime}{ }^{5}$, of a mole. cular weight of approximately 1500 on 'Chromosorb', 30-60 mesh ${ }^{6}$. The column packing was prepared by slurrying the 'Chromosorb' with a 10 per cent solution of the polymer dissolved in acetone. The acetone was evaporated at room temperature and stray volatile materials removed by heating in a vacuum oven at $130^{\circ} \mathrm{C}$. The gas chromatograph was a commercial model ${ }^{7}$ provided with a $1-\mathrm{mV}$., 1-sec. full-scale strip. chart recorder ${ }^{8}$. The detector was a 4 -filament thermal conductivity unit. The helium flow rate was $83 \mathrm{ml} . / \mathrm{min}$. measured at the column exit and at room temperature. The column and cell temperature was $205^{\circ} \mathrm{C}$. The pressure drop across the column was 30 p.s.i.g. Two mgm. of each methyl ester were dissolved in petroleum ether (b.p. $37^{\circ}$ ) and a 5-ul. sample injected into the column. Values for methyl palmitate and methyl arachidonate are included in Table 1 for comparative purposes.

Quantitative estimation of the fatty acid esters within \pm 5 per cent could be made by measuring the peak areas and comparing these values with those obtained from known amounts of the pure methyl esters.

This communication is taken from a dissertation submitted by Irwin Hornstein to the Graduate School of Georgetown University in partial fulfilment of the requirements for the Ph.D. degree.

\section{IR WIN HORNSTEIN}

L. E. ELLIOTT

P. F. CROWE

Meat Laboratory,

Eastern Utilization Research and

Development Division,

United States Department of Agriculture, Beltsville, Maryland.

1 Orr, C. H., and Callen, J. E., J. Amer. Chem. Soc., 80, 249 (1958)

"Lipsky, S. R., Landowne, R., A., and Godet, M. R., Biochim. Biophys. Acta, $\mathbf{8 1}, 336$ (1959)

Craig, B. M., and Murty, N. I., Can.J.Chem., 36, 1297 (1958).

- Grassie, N."Trans. Faraday Soc., 8.80 .

Union Carbide and Carbon Corp., Bakelite Division, New York, New York.

- Johns-Mansville, Celite Division, New York, New York.

7 A Beckman GC-2 gas chromatograph was used.

The recorder was manufactured by Minneapolis-Honeywell, Brown Instrument Division, Philadelphia, Pennsylvania.

\section{Sulphonamides with Diuretic Activity}

Recentuy we have reported that sulphonamides with a substituted amido-group that is, compounds deprived of any inhibitory action on carbonic anhydrase, may possess a high diuretic activity ${ }^{1}$. The most active compound of the series is 4-amino-6chloro-benzene-1,3-disulphonmethylamide (I).

In the meantime cyclic compounds with a free sulphonamido-group, for example, 6-chloro-7-sulphamyl-3, 4-dihydro-1, 2, 4-benzothiadiazine-1, 1dioxide (II), have received attention ${ }^{2}$.

It seemed therefore interesting to us to bring about ring-closure with formaldehyde in compound (I), and 6-chloro-7-methylsulphonamide-3, 4-dihydro2, N-methyl-1, 2, 4-benzothiadiazine-1, 1-dioxide (III) was obtained.

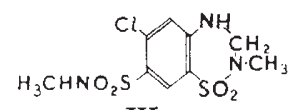
III m.p. $=202-203^{\circ}$

(Anal. calc. for $\mathrm{C}_{9} \mathrm{H}_{12} \mathrm{ClN}_{8} \mathrm{O}_{4}, \mathrm{~S}_{2}: \mathrm{C}, 33 \cdot 28 ; \mathrm{H}, 3 \cdot 71 ; \mathrm{N}, 12 \cdot 81$ $\mathrm{S}, 19 \cdot 68$; found: $\mathrm{C}, 33 \cdot 20 ; \mathrm{H}, 3 \cdot 88 ; \mathrm{N}, 1.2 \cdot 62 ; \mathrm{S}, 19 \cdot 87)$

The diuretic activity of compound (III) is of the same magnitude as that developed by (II) although it does not present an inhibitory action on carbonic anhydrase. Furthermore in low dosages it is possible to provoke diuretic activity much more-pronounced than that observed with compound (I).

On the other hand between compounds (II) and (III) there exist considerable differences. While the diuresis promoted by (II) is a rapid phenomenon and the activity decreases after a short time, diuresis promoted by compound (III) is milder and more prolonged. Moreover (III) proves to possess a lower toxicity than (II): ( $\mathrm{DL}_{50}$ intrap. in rats: (II)= $800 \mathrm{mgm} . / \mathrm{kgm}$.; (III) $=1,670 \mathrm{mgm} . / \mathrm{kgm}$.).

\section{W. LOGEMaNA}

P. N. Giraldi

Chemical Research Laboratory,

M. A. Parenti

Biological Research Laboratory,

Istituto 'Carlo Erba' per Ricerche Terapeutiche, Milano.

'Logemann, W., Giraldi, P. N., and Parenti, M. A., Nature, 182,
1510 (1958). Logemann, W., Giraldi, P. N., and Galimberti, S.,
Liebigs Ann. Chem., 623, 157 (1959). Rulli, V., Bonami, L.,
and Concina, B., Il Policlinico (in the press). Parenti, H. A.,
Il Farmaco (in the press). Giraldi, P. N., Il Farmaco (in the press).
2 de Stevens, G., Werner, L. H., Halamandaris, A., and Ricca, S., jun.,
Experientia, 14, 463 (1958).

\section{Specificity of the Tryptophan Peroxidase-Oxidase Enzyme System}

The conversion of tryptophan to kynurenic acid has been demonstrated in most mammals ${ }^{1,2}$.

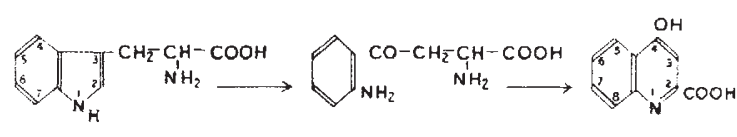
Tryptophan
Kynurenine
Kynurente Adid

The formation of kynurenine (via formyl-kynurenine), is catalysed by a coupled peroxidase-oxidase system which is regarded by Hayaishi ${ }^{3}$ and others, from in vitro experiments, as being highly specific for L-tryptophan. 